\title{
Classroom Management of Christian Religious Education During the Covid-19 Pandemic
}

\author{
Desi Sianipar ${ }^{1}$, Johanes Waldes Hasugian ${ }^{2}$, Wellem Sairwona ${ }^{3}$, Yunardi Kristian Zega ${ }^{4}$, \\ Nova Ritonga ${ }^{5}$ \\ 1,3,4 Universitas Kristen Indonesia, Indonesia \\ ${ }^{2}$ Sekolah Tinggi Teologi Sumatera Utara, Indonesia \\ ${ }^{5}$ Sekolah Tinggi Teologi Mawar Saron Lampung, Indonesia \\ desi.sianipar@uki.ac.id,johaneswhasugian@gmail.com,wellem.sairwona@uki.ac.id, \\ yunardichristian@gmail.com,novaritonga9@gmail.com
}

\begin{abstract}
During the covid-19 Pandemic that hit Indonesia, online learning became a learning model that must be done in areas with a high covid-19 spread rate. There are many challenges faced by all interested parties in the world of education. Problems include limited internet access, skills in using technology, and the ability to manage online learning classes. This study focuses on the role of Christian Religious educators or teachers in overcoming online learning problems and challenges by seeking to create a conducive and enjoyable learning atmosphere and quality so that students can learn well and achieve learning outcomes. Therefore, the purpose of this study is to describe the concept of effective online classroom management for Christian religious education learning to shape the Christian character of students during the covid-19 pandemic based on five classroom management functions, namely leading, planning, organizing, and evaluation. In order to achieve this goal, this research is qualitative-descriptive. That is, it describes data regarding Christian religious education class management during the covid-19 pandemic. The results of this study are that online classroom management for Christian religious education learning can be realized through the leadership of teachers who are servant-hearted; planning of learning activities in shaping Christian character; setting the learning process and learning materials; teacher skills in implementing learning; and teachers who always guarantee the quality of their learning through evaluation activities.
\end{abstract}

\section{Keywords}

classroom management; christian education; covid-19 pandemic

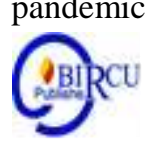

\section{Introduction}

The covid-19 pandemic has changed the education system in Indonesia. The learning process carried out face-to-face is now in various areas exposed to covid-19, turning into online or online learning. Meanwhile, in other areas where the spread of covid is not too severe, the learning process is carried out offline (outside the network) and home visits (visits to students' homes) Agnesiana, (2021). To limit this research, the focus of the discussion is on online learning.

There are many problems encountered in online learning. According to Leli Efriana, these problems include: first, not all students can easily understand the contents of reading material delivered online. Second, the limited ability of teachers to use online learning technology. Third, the limited supervision of learning due to the absence of a discussion forum menu in the application. Fourth, after filling out the attendance list, some students leave the online class until the end of learning. Fifth, students do not have gadgets or 
computers to use as learning media. Sixth, students are less enthusiastic about participating in online learning even though adequate facilities support them. Seventh, some students who live in areas have inadequate internet access. Eighth, the length of online learning lasts for months which causes students to be bored and lazy. Ninth, most parents have jobs outside the home, so they hardly monitor, guide, and assist their children in solving the difficulties they face. Tenth, some parents complain that online learning adds to their burden of spending on internet costs Efriana, (2021). All of these problems relate to the implementation of online learning. Obispo, et al. suggest that a teacher's classroom management style can also cause problems, namely, when the teacher uses an autocratic model in teaching, his style will be coercive and dictatorial. He tends to use his own experience, expertise, and understanding by ignoring the students' point of view. The authoritarian style imposes restrictions and controls on students. Likewise, the laissez-faire style gives too much freedom to students so that it ignores much inappropriate behavior, so the class becomes chaotic, uncomfortable, and lacks predictability. According to Obispo et al., (2021), the style of classroom management that greatly determines success in the teaching and learning process is the democratic style. This style creates an environment of independence in the classroom and allows students to communicate their thoughts and desires while leaving the final decision to the teacher. Based on the author's experience, another problem is that students do not come to class on time; unstable signal; students do not master the use of applications; students are not ready to take part in online learning; not all students have adequate facilities; limited quota; the place where students learn is not conducive; students are less focused because they are dealing with laptops/mobile phones, not the teacher directly; students get bored quickly; teachers are less attractive in teaching; the learning media used by the teacher is less attractive; The methods used tend to be lectures or just explaining.

The outbreak of this virus has an impact of a nation and Globally (Ningrum et al, 2020). Covid 19 pandemic caused all efforts not to be as maximal as expected (Sihombing and Nasib, 2020). In the covid-19 pandemic situation, one of the things that educators must appropriately handle to make online learning effective is classroom management. Teachers must manage learning objectives, curriculum, e-learning learning models, learning methods, and the teacher's role to make learning effective and fun for students. Classroom management is a procedure, strategy, or teaching technique used to direct student behavior and learning activities.

Several studies have shown various efforts in managing online classes. Lathifah et al., (2020) research which emphasizes technical skills in managing class. Nae, (2020) emphasizes the importance of wise teacher attitudes in managing classes during the covid19 pandemic, namely: having empathy and caring for students; be proactive in taking advantage of learning opportunities and integrating online education according to the needs of students; full consideration in providing homework by the workload of students; open to provide a particular time/schedule for students to be able to contact the teacher at the agreed time; willing to work with other teachers in order to share practices to find the best learning. Thus, online classroom management must present active, fun, innovative, creative, effective, efficient learning, knowledge and value transfer, and consistently based on quality. Therefore, in online classroom management, teachers must use five class management functions: leading, planning, organizing, actuating, and evaluation Saifulloh \& Darwis, (2020).

When classroom management is associated with learning Christian religious education, it is unique compared to other subjects, namely in its learning objectives. Christian religious education learning aims to make students more intellectually competent 
and intelligent emotionally, spiritually, and Christian character. It is in line with the goals of national education, namely to develop the potential of students to become human beings who believe and fear God Almighty, have a noble character, are healthy, knowledgeable, capable, creative, independent, and become democratic, responsible citizens (UndangUndang Nomor 20 Tahun 2003 tentang Sistem Pendidikan Nasional, pasal 3, n.d.). In Christian religious education learning, the expected result is that students can experience changes in behavior, attitudes, morals, principles of life, etc., more and more like Christ. It is a challenging task for educators because it is done online, where educators cannot directly and thoroughly see students' body movements and behavior. These situations and conditions make it difficult for educators to know and evaluate students' emotional, spiritual, and character development. Likewise, the difficulties experienced by students and parents because they cannot interact directly with educators Kusuma \& Sutapa, (2020).

Based on the problems stated above, this study aims to describe the concept of effective online classroom management for Christian religious education learning to shape the Christian character of students during the covid-19 pandemic based on five classroom management functions, namely leading, planning, organizing, actuating and evaluation. With this concept, the authors hope that it will help Christian religious educators manage online classes well.

\section{Research Methods}

This research is qualitative research with a descriptive method, which seeks to describe or describe various matters relating to classroom management in Christian religious education learning during the covid-19 pandemic. For this reason, various sources of literature or literature in the form of books and scientific journals are latest and relevant in the form of research results related to the management of Christian Religious Education classes, especially regarding the role of teachers and their challenges during the covid-19 pandemic.

\section{Results and Discussion}

This study resulted in a practical online classroom management concept for Christian religious education learning to shape the Christian character of students during the covid19 pandemic. The discussion is based on the five functions of class management, namely leadership, planning, organizing, actuating, and evaluation.

\subsection{Leading: Educators as Leaders are Servant}

Online classroom management as an effort to build the Christian character of students is in dire need of a teacher leadership model because "iron sharpeneth iron; so a man sharpeneth the countenance of his friend" (Proverbs 27:17). God places the teacher as a person whose function is to shape character, primarily through his leadership. In Christian education, one of the expected leadership models is servant leadership or servant leadership. The leadership of Jesus Christ inspires this leadership model. Scientifically, the term servant leader was first introduced by Robert Greenleaf in his writing entitled "The Servant as Leader," published in 1970. Greenleaf in Van Dierendonck said that there are ten characteristics of servant leadership: listening, empathy, healing, self-awareness, persuasion skills, conceptual thinking skills, foresight, stewardship skills, commitment to the growth of others, and the ability to build community. Van Dierendonck himself added six more characteristics, namely: the ability to empower and develop people, humility, 
self-authenticity, interpersonal acceptance, ability to give direction, and shepherding attitude van Dierendonck, (2011).

In the context of online learning, a servant leadership model is needed in Christian educators to improve the progress and success of students during the teaching and learning process. When paying attention to the problems faced by diverse students, teachers must have excellent sensitivity and concern for meeting the needs of each student. Teachers must have an attitude of heart and character to serve like Christ. The teacher must be willing to empty himself, as was Christ "who, though he was in the form of God, did not consider equality with God a thing to be grasped, but emptied himself, taking the form of a servant, and being in the likeness of men (Phil. 2:6-7)." In this case, the teacher is willing to humble himself and give extra time without demanding to be paid even though he professionally deserves additional honors. He is willing to find out the problems faced by each student, the causes of problems, and think of solutions for the benefit of students. Therefore, there are several abilities that teachers in leading students must possess. According to several studies, the ability in question is the ability to manage emotions and the ability to manage the learning process in the classroom. All of these abilities are very influential on the formation of the character of students Nancy K. Martin, et al., (2016).

Nancy K. Martin, et al., (2016) explained that the teacher's self-management aspect is vital in classroom management. Teachers must be able to control themselves, such as adjusting the intonation of speech and body language used; and managing their emotions when responding to problematic students and chaotic classrooms. Research conducted by Mangkunegara et al., (2015) and Julita et al., (2019) proves that the higher the teacher's emotional intelligence, the higher the teacher's performance in managing the classroom. Not only emotional intelligence, research conducted by Puluhulawa, (2013) found that teachers' emotional intelligence and spiritual intelligence were able to improve teachers' social competence in their interactions, both with students, principals, fellow teachers, professional colleagues, and parents of students. Teachers can no longer force students, especially in online learning situations. Thus, the classroom management model that only emphasizes student discipline and strict control using school rules needs to be changed to dynamic classroom management that focuses on creating a more positive and comprehensive learning environment Davis, (2017).

One of the effective leadership approaches in dynamic classroom management is the humanist approach, in which the teacher views students as God's creations who are equal to himself so that the relationships built with students are partners in the teaching and learning process. Therefore, of a teacher's four classroom management styles, namely autocratic, authoritative, democratic, and permissive or laissez-faire, the democratic style is the most effective in producing an environment that allows students to develop dynamic social relations between teachers and students more openly. Groome, (2014) said that the students are our traveling brothers and sisters, fellow pilgrims, who at the same time are called to be history makers in order to present the Kingdom of God on earth, who together learn to become more and more like Christ. Therefore, Groome rejects the teacher-student relationship as a subject-object relationship but must be a subject-subject relationship. In the context of a more humane digital learning, Giudici et al. said that because young people are familiar with technology, the teacher's role needs to be modified to become a mentor, mediator, guide, facilitator, learning coordinator, assessor, and designer, as well as the constructor of learning tools Aguado \& Eizaguirre, (2020). The individual teaching and learning process in meeting the needs and interests of students will produce more autonomous individuals. Students quickly become individualistic because they relate more to digital devices than to fellow disciples of Christ, who are also undergoing the same 
pilgrimage field in the digital world. Therefore, the contribution of information and communication technology must be appropriately managed. Teachers and students must realize that the human journey to become mature in Christ is a journey together and not just walking together.

When students begin to show individualistic tendencies, the democratic approach is no longer enough because the equality given to students has turned into unlimited freedom that can make them act as they please. If this is allowed to happen, the teacher's leadership style will become permissive leadership. When the teacher shows himself as the only authority in the classroom, his leadership becomes autocratic. When the teacher makes boundaries and rules as the highest authority in the class that must be followed only by students, then the teacher leads authoritatively. Therefore, democratic leadership must still be maintained without being trapped in a permissive, authoritative, and autocratic approach. The teacher must still have the soul and character of a servant for all. Democratic servant leadership in managing the classroom is maintained, emphasizing the subject-subject relationship, which views students as equal to teachers. His servant approach is seen when the teacher appears to serve other subjects who have difficulty teaching and learning. Just as Christ came to this world, not to be served but to serve, even to give His life for the salvation of the whole world (Mark 10:45), so teachers who take on the role of servants must also be willing to give their lives for the success of their students.

\subsection{Planning: Planning of Christian Religious Education Learning Activities in Forming Christian Character \\ God created humans very well, and every human being is given a different character.} These different characters become a beauty that deserves to be appreciated. Therefore, Christian educators need to be aware of and appreciate the differences in the character of each student. It can happen if educators have good relationships and communication with students Debora \& Han, (2020). Although each student has been created with a unique character, they still have to be shaped according to the pattern of Christian character so that their lives can be in harmony with the will of Christ. Christian character is a spiritual seed planted in the self and the mind of believers that must be built continuously based on faith in Jesus Christ and personal fellowship with God in the power of the Holy Spirit. It means that the true Christian character is the character that reveals the glory of God to the world, where these people (believers) can be a blessing to others (salt and light of the world) Metanfanuan \& Hetharia, (2021). For this reason, Christian religious teachers need to make learning plans based on Christian character.

Planning for character-based learning must prioritize aspects of inculcating moral values or character for students. Many dimensions must be considered in preparing a character-based learning plan Nadlir, (2016). According to Harjanto in Rusydi Ananda, explaining the content of a good learning plan needs to include: 1) objectives, namely what is desired as a result of the educational process; 2) Programs and services, namely organizing learning activities and supporting services; 3) Human resources, namely human resources that include ways to develop achievement, specialization, behavior, competence, and satisfaction; 4) Facilities include how to take advantage of the use of existing facilities, 5) Finance, which includes expenditure plans and revenue plans, 6) Organizational structure, namely how to organize and manage the operation and supervision of planned educational programs and activities, and 7) context social or other elements that need to be considered Ananda, (2019).

In the context of classroom management, educators must pay attention to the Christian religious education learning design in shaping the Christian character of students 
during the covid-19 pandemic, as follows: first, the preparation of human resources (Christian religious educators). In shaping the Christian character of students, the Christian religious educator must be experienced being born again so that the teacher involves the Holy Spirit in all his work, including in shaping the Christian character of students Debora \& Han, (2020). Metanfanuan \& Hetharia, (2021) said that any strategies and approaches could be used by teachers in shaping the Christian character of students, but without involving the Holy Spirit, everything will be in vain. Therefore, experiencing a new birth is the main requirement for Christian religious educators to form the Christian character of students. In addition, in preparing human resources, the thing that must be considered is the teacher's skills in classroom management. For that, they need to receive regular training. Research by Fatma Sadik and Tugay Akbulut states that successful teachers in classroom management are influenced by their academic and pedagogical background and skills and experience in classroom management. However, most literature shows that teachers who spend much time on classroom management feel inadequate and need training Sadik \& Akbulut, (2015).

Second, make a learning plan. Making lesson plans is very important for teachers so that the learning process can run with clear directions and goals. Specifically for online learning, learning outcomes must be determined, learning objectives, materials, activities, learning methods, learning resources, learning time and length, forms of evaluation of learning outcomes, assessment criteria, rating scales, and so on. The assignments are also well designed. Then all that must be conveyed to the students at the beginning of the lecture. All designs must also be adjusted and considered with the situation and condition of each student's readiness in undergoing online learning. Last and not least, all learning designs are used in such a way significantly to shape the Christian character of each student.

Third, make a systematic learning material. Before learning is carried out, Christian religious educators need to prepare lesson materials that are arranged systematically. The preparation of lesson materials will help teachers in teaching their students. For example, outlining includes 1) introduction, 2) core learning, 3) conclusion and application, 4) sources or references used. It will be helpful for the teacher so that the discussion will not come out of the material that has been prepared, optimize the available time, and make the learning process more effective and efficient.

Fourth, determine the appropriate learning method according to the situation. It is, of course, a new task for teachers to think of varied learning methods during the current pandemic so that students can still enjoy the learning atmosphere even in minimal circumstances. Therefore, teachers should not only focus on using one monotonous method. However, teachers need to think about, seek, and learn about using other methods, especially online learning during the current covid-19 pandemic.

Fifth, the arrangement of the classroom. Even in the context of online learning, there are still managed classrooms, namely virtual classrooms. If learning is carried out in a real classroom, it is necessary to pay attention to the classroom arrangement, including comfortable classrooms, adequate classroom facilities, good air circulation, and good lighting Harahap et al., (2019). However, in online learning, the arrangement includes: the provision of material in an orderly and neat manner in the application system or learning management system (LMS) used, adequate internet network quality, the ability of participants to use learning application systems, etc.

Sixth, create unique programs or services for students. Based on research results in the United States and China during the current covid-19 pandemic, many students experience stress Wang et al., (2020). It is similar to what happened in Indonesia. The 
factors that cause student stress are certainly various problems. To know this, this is where the vital role of Christian religious educators is to create unique programs or services to help their students. For example, teachers can make particular schedules outside class hours to provide guidance and counseling for their students, both in groups and in private if needed Sutarto \& Sari, (2020). With this, the teacher can determine the next step, how to provide the right solution to solve every problem faced by his students based on Christian teachings. In this way, the teacher can get to know each student well.

Seventh, as in offline learning, classroom management requires collaboration between teachers, academic administration, counseling services, parents, and online learning. The results of research by Fatma Sadik and Tugay Akbulut, stated that the cooperation of these four parties was felt to be very lacking for the benefit of classroom management, so that this hampered learning achievement Sadik \& Akbulut, (2015).

Eighth, planning evaluation activities. In general, the benefits of evaluation activities include: 1) in order to understand students, facilities, infrastructure, and existing situations/conditions, 2) to make decisions in determining the following program, and 3) to improve the quality of learning so that it is more qualified B., (2017). Therefore, in shaping the Christian character of students, it is also essential for teachers to design evaluation activities. By making the learning objectives an indicator, the teacher can see the extent of success that has been achieved and know what things must be improved in the future to be better.

\subsection{Organizing: Organizing the Learning Process and Creating Materials Christian Character Building}

The class organization is an equally important part of classroom management because it aims to regulate the activities of human resources and other resources so that learning can be carried out effectively and efficiently. Therefore, the teacher must organize the class well after conducting class planning in a directed manner and having goals, actions, resources, methods, and techniques to be used. After that, the teacher can organize the class, which includes: determining the resources and activities needed, determining and developing study groups, giving responsibility to students through assignments, and giving authority to students in class management Karwati \& Priansa, (2019).

Resources in education in schools can be grouped into four: human resources, nonhuman resources, physical resources, and financial resources Hermawan, (2010). When organizing classes in online learning, teachers need to pay attention to all these types of resources because they significantly affect the teaching and learning process. For this reason, good teachers need to understand their abilities and the abilities of their students correctly. The readiness of these resources is very closely related to the activities that the teacher will make to achieve the learning objectives.

To avoid monotonous learning, teachers need to design and develop study groups by dividing students variedly, meaning that the teacher deliberately determines each student in study groups with varied abilities. The goal is that each student can learn from each others and help each other. The existence of active students is expected to help or helpless active students. For online classes, teachers can define and divide small study groups by creating a small study group (breakroom) that can be monitored by the teacher simultaneously.

In addition to enlivening the learning atmosphere, teachers also need to improve students' character by giving them responsibility for completing tasks both in groups and individually. Giving this responsibility will foster students' self-confidence and exercise responsibility for the tasks given under the agreed time. For this reason, teachers need to pay attention to the weight of the assignments given to students, the level of difficulty, the 
time required to complete them, and the benefits of the assignment itself to the development of students both in terms of knowledge, attitudes, and skills. It needs to be considered, considering that teachers cannot accompany students directly and can only control and direct from afar. Do not let the given task make students feel embarrassed because they are not able to do it. In this case, the teacher must be aware that the conditions and situations of online learning are different for each student, which is also very different from offline or face-to-face learning.

Managing an online class is not the same as managing an offline class. However, teachers can still delegate class management authority to students, where other students who are considered more technologically proficient can assist teachers in managing online classes, for example, helping their friends display the results. Work or other student tasks and can also assist teachers in controlling other students during the learning process.

Teachers need to organize curriculum, classroom or school buildings or facilities, teachers, students, and class dynamics to realize good classroom organization Manda, (2016). Associated with online learning, classroom or school buildings or facilities can be interpreted as rooms and applications used by teachers in the learning process, while class dynamics is an online classroom situation that is certainly very different from offline classes. It is very influential on the continuity of learning.

\subsection{Actuating: Skilled in Implementing Teaching and Learning}

The success of learning activities cannot be separated from the expertise or performance of Christian religious educators in implementing them. Christian religious educators who want to plan or design lessons indicate seriousness or perseverance in teaching students. At the same time, the next task and a struggle for Christian religious educators are to implement learning designed in such a way. It has become a phenomenon when the implementation of learning does not run optimally by previously designed learning strategies. In managing learning, Christian religious educators face global pandemic conditions that impact the learning process. Compared with the situation before the covid-19 pandemic, teachers currently find more complex problems in the learning process that teachers are required to adapt Sihotang, (2020).

The new adaptation in learning during the covid-19 pandemic is intended so that schools and Christian religious educators can ensure that the needs or interests of students can be adequately met so that students gain meaningful learning experiences as they should. Both students and teachers have new roles in online learning, and the main challenge for teachers in online learning is to facilitate learning so that students acquire sound knowledge and have self-leadership and collaboration with classmates Conrad \& Donaldson, (2011).

For this reason, the skills of Christian religious educators are the key in that direction. When digitizing learning becomes a must in learning, Christian religious educators must increase capacity, skills, and creativity in online learning Hutapea, (2020). Tari \& Hutapea, (2020) view that in dealing with or assisting students who have not been able to use information technology optimally, Christian religious educators must develop themselves professionally in terms of mastering information technology.

Information technology is an instrument (tool) used to facilitate the achievement of learning objectives. Christian religious educators must pay attention to other vital aspects in carrying out online learning include learning and communication models that encourage excellent and constructive relationships. To manage online-based Christian religious education learning, applying the suitable model, which includes interaction, exploration, and elaboration. Educators allow students to move freely, participate, explore and evaluate 
information, process information, and solve problems individually or in groups. With a learning climate that adopts this, rigorous rote learning (verbalizes or rote learning) becomes irrelevant Boehlke, (1962), especially in online learning during the covid-19 pandemic. In addition, communication in learning is essential and becomes an essential skill for teachers in teaching. Teachers and students who have good communication and relationships in learning will appreciate the class and show interest in teaching and learning Duţă, (2015). The warm relationship built in the online classroom will make children aware to always learn proactively and interactively, build respect for one another, change the mindset of children in learning, mobilize creative ideas, generate motivation, and build good teacher-student relationships.

\subsection{Evaluating: Always Guaranteeing the Quality of Learning}

Evaluating activities should not be ignored in the Christian religious education class management process to produce the best or superior learning achievements. It is necessary to determine the teacher's success rate of classroom management is by what is expected, namely to create a pleasant learning atmosphere so that learning objectives can be achieved. Endah Ratnaningsih stated that evaluation is a research process to collect data from various sources to produce good decisions for improving or developing a program. The evaluation aims to describe organizational achievements, explain them, and determine ways of further development. This evaluation action should come from the internal motivation of an organization manager to see whether the organization's achievements are by what was planned or expected. Evaluation is also carried out to meet external demands or related to the funding of the organization. Evaluation can be carried out by internal parties experienced in the field of evaluation, external parties, or both parties through collaboration Ratnaningsih, (2017). In terms of classroom management, what is meant by evaluation is not the evaluation of learning outcomes or learning but the evaluation of programs.

The things that are evaluated are based on the Christian religious education class management planning that has been done before starting the lesson. Class management planning should be contained in a particular document to be used as a basis for implementation and evaluation. Evaluation activities can be carried out in the middle of the semester (formative evaluation) and at the end of the semester (summative evaluation). Rusydi Ananda and Tien Rafida stated that when evaluation is intended to improve and develop ongoing activities. If the evaluation is intended to provide accountability, information, follow-up, then the evaluation is summative Ananda \& Rafida, (2017).

In particular, in evaluating Christian religious education online learning programs, several principles must be considered by learning managers, namely: 1) planning and evaluation by setting evaluation methods, data collection instruments, processing methods, and analysis techniques, 2) Learning managers determine evaluators by first provide training to them so that the evaluation process is carried out according to the established rules or principles; 3) The evaluator presents a report on the results of the evaluation; 4) Learning managers and evaluators discuss findings in online classroom management evaluations; 5) The learning manager establishes a decision or policy as a follow-up to the results of the online classroom management evaluation. 


\section{Conclusion}

Teachers face many problems and challenges in carrying out online learning during the covid-19 pandemic, especially in learning Christian religious education. Learning managers and Christian religious educators must try as optimally as possible to overcome them by managing online learning classes. Teachers must manage learning objectives, curriculum, e-learning learning models, and learning methods to be practical and fun for students. Thus, learning objectives can be achieved as planned or expected. Several stages included in classroom management are leading, planning, organizing, actuating, and evaluation. In online learning amid the covid-19 pandemic situation, the role of the teacher as a servant leader is needed to help and overcome the difficulties of students who are experiencing mental stress due to various limitations or obstacles they face. Teachers must try to make the learning atmosphere conducive and fun so that learning objectives can be achieved. In planning, teachers must prepare good classroom management to create a conducive learning atmosphere and shape Christian character as the goal of Christian Religious Education. Several things need to be prepared, namely: human resources who can manage classes well, lesson plans, systematics of learning materials, learning methods, classroom arrangement, counseling guidance services, teacher collaboration, academic administration, counseling services, and parents, as well as evaluation activities.

Regarding the organization, the teacher must regulate the learning process and create Christian character-building materials. The teacher organizes the curriculum, building or classroom or school facilities, teachers, students, and class dynamics in online learning. Furthermore, teachers must also be skilled in carrying out learning by paying attention to the adaptation process to the new learning system, teacher skills, and communication and teacher-student relationships. Finally, the teacher must evaluate the classroom management that has been carried out to determine how much achievement has been made and the failures to produce decisions or policies for improvement or improvement in classroom management.

\section{References}

Agnesiana, B. (2021). Wajah Pendidikan Agama Kristen di Masa Pandemi. Adab.

Aguado, R., \& Eizaguirre, A. (Eds.). (2020). Virtuous Cycles in Humanistic Management. Springer International Publishing. https://doi.org/10.1007/978-3-030-29426-7

Ananda, R. (2019). Perencanaan Pembelajaran. Lembaga Peduli Pengembangan Pendidikan Indonesia (LPPPI).

Ananda, R., \& Rafida, T. (2017). Pengantar Evaluasi Program Pendidikan. Perdana Publishing.

B., M. (2017). Evaluasi Belajar Peserta Didik (Siswa). Jurnal Idaarah, Vol.1(2), 257-267.

Boehlke, R. R. (1962). Theories of learning in Christian education. Westminster Press.

Conrad, R.-M., \& Donaldson, J. A. (2011). Engaging the online learner: Activities and resources for creative instruction (Vol. 38). John Wiley \& Sons.

Davis, J. R. (2017). From Discipline to Dynamic Pedagogy: A Re-Conceptualization of Classroom Management. Berkeley Review of Education, 6(2), 129-153.

Debora, K., \& Han, C. (2020). The Significance of the Role of Christian Teachers in Building Students' Character in Christian Education: A Study of Christian Ethics. Diligentia: Journal of Theology and Christian Education, 2(1), 1. https://doi.org/10.19166/dil.v2i1.2212 
Duţă, N. (2015). From theory to practice: the barriers to efficient communication in teacher-student relationship. Procedia-Social and Behavioral Sciences, 187, 625630.

Efriana, L. (2021). Problems of Online Learning during Covid-19 Pandemic in EFL Classroom and the Solution. JELITA, 2(1), 38-47.

Groome, T. H. (2014). Christian Religious Education: Berbagi Cerita dan Visi Kita. BPK Gunung Mulia.

Harahap, S. E., Dausat, J., \& NizanFadila. (2019). Class Managenent Design for Condusive and Exciting Learning. Proceeding International Seminar on Islamic Studies, 1(1), 2019.

Hermawan, R. (n.d.). Pengembangan Sumber Daya Sekolah. http://file.upi.edu/Direktori/JURNAL/PENDIDIKAN_DASAR/Nomor_13April_2010/Pengembangan_Sumber_Daya_Sekolah-Ruswandi_Hermawan.pdf

Hutapea, R. H. (2020). Kreativitas Mengajar Guru Pendidikan Agama Kristen Di Masa Covid-19. Didaché: Journal of Christian Education, 1(1), 1-12.

Julita, S., Herawaty, D., \& Gusri, S. A. (2019). PENGARUH KECERDASAN EMOSIONAL, DAN SELF EFFICACY TERHADAP KINERJA GURU MATEMATIKA. JUPITEK: Jurnal Pendidikan Matematika, 2(1), 31-34. https://doi.org/10.30598/jupitekvol2iss1pp31-34

Karwati, E., \& Priansa, D. J. (2019). Majanemen Kelas (Classroom Managemen) Guru Profesional yang Inspiratif, Kreatif, Menyenangkan, dan Berprestasi. Alfabeta.

Kusuma, W. S., \& Sutapa, P. (2020). Dampak Pembelajaran Daring terhadap Perilaku Sosial Emosional Anak. Jurnal Obsesi : Jurnal Pendidikan Anak Usia Dini, 5(2), 1635-1643. https://doi.org/10.31004/obsesi.v5i2.940

Lathifah, Z., Khusnul, F. H., \& Maryani, N. (2020). The practice of effective classroom management in COVID-19 time. International Journal of Advanced Science and Technology, 29(7), 3263-3271.

Manda, M. (2016). Fungsi Pengorganisasian dan Evaluasi Peserta Didik. Kelola: Journal of Islamic Education Management, 1(1), 89-101. https://doi.org/10.24256/kelola.v1i1.432

Mangkunegara, Prabu, A. A. A., \& Puspitasari, M. (2015). Kecerdasan Emosi,Stres Kerja, Dan Kinerja Guru SMA. Jurnal Kependidikan, 45(2). https://doi.org/10.21831/jk.v45i2.7491

Metanfanuan, T., \& Hetharia, C. (2021). Pendidikan Kristiani Sebagai Sarana Pembentukan Karakter Anak-anak Suku Moi, Distrik Klamono, Sorong, Papua Barat. EPIGRAPHE: Jurnal Teologi Dan Pelayanan Kristiani, 5(1), 49. https://doi.org/10.33991/epigraphe.v5i1.199

Nadlir, M. (2016). Perencanaan Pembelajaran Berbasis Karakter. Jurnal Pendidikan Agama Islam (Journal of Islamic Education Studies), 1(2), 338. https://doi.org/10.15642/jpai.2013.1.2.338-352

Nae, N. (2020). Online learning during the pandemic: where does Japan stand. Euromentor Journal, XI(2), 7-24.

Nancy K. Martin, Nancy Jo Schafer, Sandee McClowry, Edmund T. Emmer, Mieke Brekelmans, T. M., \& Wubbels, T. (2016). Expanding the Definition of Classroom Management: Recurring Themes and New Conceptualizations. The Journal of Classroom Interaction, 51(1), 31-41.

Ningrum, P. A., et al. (2020). The Potential of Poverty in the City of Palangka Raya: Study SMIs Affected Pandemic Covid 19. Budapest International Research and Critics Institute-Journal (BIRCI-Journal) Volume 3, No 3, Page: 1626-1634 
Obispo, R. T., Magulod, G. C., \& Tindowen, D. J. C. (2021). Teachers' Classroom Management Styles and Student-Teacher Connectedness and Anxiety. International Journal of Learning, Teaching and Educational Research, 20(5), 123-141. https://doi.org/10.26803/ijlter.20.5.7

Puluhulawa, C. W. (2013). Kecerdasan Emosional dan Kecerdasan Spiritual Meningkatkan Kompetensi Sosial Guru. Makara Human Behavior Studies in Asia, 17(2), 139. https://doi.org/10.7454/mssh.v17i2.2957

Ratnaningsih, E. (2017). Evaluating a Classroom Process. Journa of English Language, Literature, and Teaching MATATHESIS, 1(1).

Sadik, F., \& Akbulut, T. (2015). An Evaluation of Classroom Management Skills of Teachers at High Schools. Procedia-Social and Behavioral Sciences, 191, 208-209.

Saifulloh, A. M., \& Darwis, M. (2020). Manajemen Pembelajaran dalam Meningkatkan Efektivitas Proses Belajar Mengajar di Masa Pandemi Covid-19. Bidayatuna: Jurnal Pendidikan Guru Mandrasah Ibtidaiyah, 3(2), 285. https://doi.org/10.36835/bidayatuna.v3i2.638

Sihombing, E. H., Nasib. (2020). The Decision of Choosing Course in the Era of Covid 19 through the Telemarketing Program, Personal Selling and College Image. Budapest International Research and Critics Institute-Journal (BIRCI-Journal) Volume 3, No. 4, Page: $2843-2850$.

Sihotang, H. (2020). Penggunaan Media Teknologi Informasi dalam Pembelajaran Pendidikan Agama Kristen di Masa Pandemi Covid-19. IMMANUEL: Jurnal Teologi Dan Pendidikan Kristen, 1(2), 63-75.

Sutarto, S., \& Sari, D. P. (2020). Group Guidance as an Alternative Method to Building Religious Character. KONSELI : Jurnal Bimbingan Dan Konseling (E-Journal), 7(2), 129-138. https://doi.org/10.24042/kons.v7i2.7064

Tari, E., \& Hutapea, R. H. (2020). Peran Guru Dalam Pengembangan Peserta Didik Di Era Digital. Kharisma: Jurnal Ilmiah Teologi, 1(1), 1-13.

Undang-Undang Nomor 20 Tahun 2003 tentang Sistem Pendidikan Nasional, pasal 3. (n.d.).

van Dierendonck, D. (2011). Servant Leadership: A Review and Synthesis. Journal of Management, 37(4), 1228-1261. https://doi.org/10.1177/0149206310380462

Wang, X., Hegde, S., Son, C., Keller, B., Smith, A., \& Sasangohar, F. (2020). Investigating Mental Health of US College Students During the COVID-19 Pandemic: CrossSectional Survey Study. Journal of Medical Internet Research, 22(9), e22817. https://doi.org/10.2196/22817 